DOI https://doi.org/10.36059/978-966-397-242-8-16

\author{
Чонка T. C., \\ кандидат філологічних наук, \\ доцент кафедри філології (українське відділення) \\ Закарпатського угорського інституту імені Ференца Ракоці II, \\ м. Берегово

\section{ТВОРЧА РЕАЛІЗАЦІЯ НОВОЇ КУЛЬТУРИ ДІАЛОГУ У ЛІТЕРАТУРНІЙ СПАДЩИНІ ВОЛОДИМИРА НАБОКОВА}

Анотація. У дослідженні доведено, що діалог між автором, героєм і читачем є основою життєтворчості художнього твору тим, що робить його суб`єктом, а не об єктом сприйняття $i$ функціонування в культурі. Переосмислено у перспективі діалогіки поняття "автор”, „герой”, „читач” як учасників художньої комунікації. Виявлено багатовекторність функцій автора, героя $i$ читача у процесі творчості-інтерпретації. Досліджено закономірності й особливості діалогу „автор - герой - читач” у творах В. Набокова. Простежено діалогічну сутність художнього мислення автора. Окреслено своєрідне розуміння Набоковимавтором інших учасників художньої комунікації. Класифіковано та систематизовано основні типи героїв і читачів у його творах; здійснено спробу нового прочитання комунікативних моделей „автор - герой”, „автор - читач”, „герой - читач”, „автор герой - читач" у творчості В. Набокова. Визначено специбіку ігрового характеру інтелектуальної прози письменника.

\title{
Вступ
}

Аксіоматично, що саме життя, вектори його розвитку залежать від рівня духовного розвитку людства, а отже - й від філософської проблеми розуміння, яка в літературі репрезентована через феномени взаєморозуміння.

Щодо постатей автора, героя та читача, у літературознавстві час від часу виникали дискусії про їх місце та значущість у процесі творення і сприймання художніх світів. Це розуміння змінювалося під впливом різноманітних факторів об`єктивного та суб`єктивного плану, серед яких - літературний напрям, рід, жанр, стиль, мода, уподобання та інші аспекти. 
Вивчення діалогу на різних рівнях у теорії літератури і втілення його у творчих доробках митців XX ст. визначає коло актуальних питань сучасного літературознавства. Проблема типології автора, героя, читача входить до іншої, складнішої - співвідношень „автор герой - читач”, які ми у своєму дослідженні називаємо „діалогом”. Спираючись на низку праць (Р. Барта, М. Фуко, М. Бахтіна, О. Потебні, Ю. Лотмана, Л. Гінзбург, М. Римаря, М. Гіршмана, М. Гольберга та ін.) об'єднуємо окремо взяті взаємини „автор читач”, „автор - текст”, „автор - герой”, „герой - читач” в єдину цілісність, що визначається діалогом i його законами $\mathrm{y}$ філософському, психологічному та естетичному сенсі.

ХХ ст. характеризується особливою увагою до „теорії діалогу” та концепту „гри” у всіх гуманітарних галузях людського пізнання. Зокрема, це стосується літературознавства, яке звертається до цих понять через пошуки нових підходів розуміння/інтерпретації художньої творчості (концептуальними у цьому плані $\epsilon$ праці М. Бахтіна та М.Зубрицької). Водночас ці феномени стають предметом, об'єктом і методом креації та рецепції самих митців. Яскравим прикладом цього $є$ творча постать Володимира Набокова. Він $€$ одним із чільних представників інтелектуальної (для більшості читачів „важкої”) прози, яка заснована на засадах гри як способу побудови діалогу з героями та читачами.

\section{1. Автоінтерпретація В. Набокова як спосіб побудови ділогу з читачем}

Щодо самого В. Набокова, то його погляди на мистецтво і власну персону були дещо екстравагантні. „Навіщо я взагалі пишу? Щоб отримувати задоволення, щоб перемагати труднощі. Я не переслідую при цьому жодних соціальних цілей, не навіюю жодних моральних уроків. Я просто люблю творити загадки i супроводжувати їх витонченим рішенням", - у цих словах втілюється творче кредо В. Набокова, та й не лише творче, але й життєве також, про що свідчать його сучасники. У житті він був „обсерватором” і власного життя, і життя оточуючої його дійсності. Митець мав феноменальну пам'ять, особливо зорову (не раз зізнавався, що вона йому іноді заважає, загромаджуючи свідомість), у чому нас переконують його автобіографічні романи.

В.Набоков уважав, що з написанням прози або віршів нічого спільного не мають хороші людські риси, чи то релігія, чи то духовні 
запити, чи то відгук на сучасне життя. Реальність, на його думку, - це нескінченна низка кроків, рівнів розуміння, і тому вона неосяжна, іiі ніхто не може зрозуміти, а людина живе, оточена більш або менш таємничими предметами. Письменник бачив насамперед безконечне розмаїття одиничного і багатство неповторних деталей. На його думку, митець бачить саме відмінність, а подібність бачить профан.

Його часто звинувачували у неповазі до оточення: мовляв, В. Набоков не поважає думку більшості, а головне - думку авторитетів, починаючи від Достоєвського, Чернишевського i закінчуючи Фройдом. Та він ніколи і ні в чому не хотів когось повторювати, боявся бути на когось схожим - і в житті, і в творчості. Про це свідчать і герої його творів, наприклад, герой роману „Подивись на арлекінів”. Саме це й було причиною відмови від будьяких літературних течій, традицій або вподобань. Гадаємо, що В. Набоков, відмовляючись від приналежності до конкретних літературних напрямів і шкіл, створює власний стиль, беручи від них окремі прийоми: „споглядальність” від натуралістів, „два світи” від романтиків, вишуканість від бароко, „кольоровий слух” та тезу „життя наслідує мистецтво” від символістів, ритмічну мову від імпресіоністів, елітність від класицизму.

В. Набоков підкреслював, що міг би назвати себе прихильником теорії мистецтва для мистецтва, якщо б ця теорія і її адепти не стали такими буденними та загальнодоступними. Єдиною формою спільноти, яку він визнавав, $є$ рівноправний діалог неповторних, поважаючих свою різність і тому близьких душ. Це діалог, подібний до уявних розмов Федора Годунова-Чердинцева з Кончеєвим в „Дарі” (хоча скептик скаже, що це ж усього лише фантом, плід хворої уяви, адже людина розмовляє сама з собою!) або ж до незакінченої шахової партії двох геніїв у „Захисті Лужина”; це вільний союз, що не залежить від жодних нав'язаних приязней або симпатій, чи то від моди в суспільстві, у яких він вбачав насилля над особистістю, шаблон, штамп, банальність - усе те, що він називав брутальністю. Для В. Набокова „брутальність” $є$ визначною рисою, що характеризує сучасну цивілізацію, в якій накопичилась багатовікова груда „протухлих” традицій і в естетичному, і моральному плані. На його думку, такі великі слова, як „Краса”, „Любов”, „Природа”, „Істина” та їм подібні, стають маскою і власним негативним відбитком, коли їх вимовляє самовдоволена брутальна людина. А „брутальний”, в його розумінні, - це, передовсім, псевдо-значущий, псевдо-розумний, 
псевдо-красивий. Щире, душевне, добре ніколи не містить у собі брутальності. Тому В. Набоков так напружено вдивлявся в довколишню дійсність, намагаючись викрити брутальність, боячись бути навіть у дрібниці близьким до неї.

Улюблена набоковська теза стосується того, що життя наслідує літературу, а не навпаки. Девізом В. Набокова залишається естетичне служіння мистецтву. Він твердить, що мистецтво - це "чудовий обман", а цінність твору залежить не від того, що сказано, а від того, як це сказано, від блискучого поєднання окремих частинок. В.Набоков, за словами О. Михайлова, погордливо відкидав реальність, у словесному мистецтві переважно бачив чудову і безкорисливу гру розуму й уяви [Див.: 7, с. 47].

Гармонійна цілістність, 3 погляду письменника, створюється лише у тому випадку, якщо усе особисте, пережите і відчуте митцем вдається, як висловився герой „Дару”, „так перетасовать, перекрушить, смешать, разжевать, отрыгнуть... что от автобиографии останется только пыль, - но такая пыль, из которой делается самое оранжевое небо" [12, т. 3, с. 328]. Мета мистецтва, вважає В.Набоков, лежить напроти його джерела, тобто у місцях піднесених і безлюдних, а зовсім не в густо заселеній сфері душевних виливань, а тому будь-який реальний спогад, будь-яка реальна емоція, будь-який реальний біографічний факт повинні бути включеними у нову систему зв'язків, щоб стати частиною „цілого”.

Для В.Набокова важливі тільки дві речі - талант та окрема особистість: „У картинах і книгах мене цікавить тільки талант. Не загальні ідеї, а особистий внесок <..>. Твір мистецтва не має жодного значення для суспільства. Він $є$ важливим тільки для окремої людини, і тільки окремий читач важливий для мене" [9, с. 158]. Саме у цих словах є справжній В. Набоков, і доказом цього служить уся його творчість, присвячена дружині Вірі та синові Дмитру (особливо просякнуті людяністю і правдивістю, ніжністю і любов'ю останні романи письменника, зокрема автобіографічний роман „Пам'яте, говори”). Свобода слова, свобода думки, свобода мистецтва - єдине, що має для нього значення, адже творчість, як і життя, без свободи неможлива [9, с. 159].

Для В. Набокова і його героїв-митців повсякденне життя - це міраж, омана, напівсон, який є лише неточною копією ідеального світу, цирковою афішею, декорацією, де письменникові даровано Богом (а героєві автором) уміння творити нові світи. „Божественною грою” 
називає В.Набоков творчість. Божественною, тому що у творчості митець найбільш близький до Творця. Грою, тому що все, що він створив, є усього лише художня, хай і яскрава, реальність. Метою митця, за Набоковим, $є$ виявлення законів, що керують гармонією в природі. I тільки сама творчість може дати відчуття гармонії у єднанні зі Всесвітом. „Творчість”, за Набоковим, дорівнює „життю”, а антитезою творчості є „смерть”, оскільки мистецтво якоюсь мірою має свої витоки з потойбічного джерела, про що йдеться у „Дарі”.

Зазвичай талановитій людині важко у реальному світі. Але їй дарується одкровення Боже - дар творити нові повнокровні, яскраві світи і населяти їх людьми. Чим більший Дар, тим більша відповідальність.

В.Набоков в одному з інтерв'ю зізнається: „я знаю більше, аніж можу виразити словами, і те <..>, що я можу виразити, не було б виражене, якби я не знав більшого" [9, с. 168]. Цинциннат Ц. також відчуває, що володіє якоюсь таємницею, і якщо не зуміє її висловити, то збожеволіє. Звичайно, що цю таємницю дарує їм автор як своєрідний знак довіри і знак причетності до Божества, що створило їх.

С. Давидов визначив це таємне знання у Набокова як „гносеологічне знання”, що в його основі лежить містичне пізнання. Гносис - це знання, що само по собі приносить спасіння й зцілення. Гностик може отримати його в акті божественного одкровення, головним чином через посередника - Спасителя чи Посланця [Див.: 2, с. 476-490]. Сергій Давидов переконливо доводить, що героя роману „Запрошення на страту” засудили на смерть тому, що він володів саме таким знанням. Це знання передав йому „посланець слова" - автор, котрий створив Цинцинната за своїм образом.

Для В. Набокова це одкровення відбулося через посередництво кольору: він володів „кольоровим слухом” - для нього кожна буква мала свій власний колір. Витоки своєї творчості В. Набоков вбачав у „легких”, але невиліковних галюцинаціях і кольоровому слухові. В одному з інтерв'ю на запитання про цей його талант він відповів: „Колір. Думаю, я народився художником - справді! <...> Відчуття кольору, любов до кольору у мене були все життя. Це називають кольоровим слухом" [9, с. 145]. Цікавим $€$ факт, що кольоровим слухом були обдаровані, окрім Набокова, його дружина та син. Цим же даром наділив він і головного героя „Дару”.

Письменник розповідав, що книга, яку він пише, спочатку зароджується і росте всередині нього, і порівнював це відчуття 3 
видінням певної картини: “цей готовий твір, недостатньо освітлений у моїй свідомості, можна порівняти 3 картиною <...> я можу скерувати свій ліхтарик на будь-яку частину чи частинку картини, коли почну записувати її на папір" [9, с. 157].

Герой “Дару” Федір також зізнається Зіні (яка уособлювала ідеального читача): “Я как будто помню свои будущие вещи, хотя даже не знаю, о чем будут они. Вспомню окончательно и напишу” [12, т. 3, с. 174]. Тобто майбутні речі вже існують у певній ірреальній сфері, яка непідвладна земному часові, і письменник тільки записує їх. Цілком можливо, що ця версія йде ще від греків, які вважали пам'ять “джерелом безсмертя”. Письменник у такому випадку несе в собі для людей не тільки пам'ять, але й життя, і безсмертя. I та пам'ять втілюється у створених митцями речах: чи то текстах, чи то картинах тощо.

В. Набоков - людина оригінальна, незалежна від думки оточення, він не потребує авторитетів і схвалення публіки; митець, що геніально реалізував себе у власній творчості і залишився у ній безсмертним для свідомості реципієнтів. Щоб відбулася природна рецепція, саме від читача залежить, чи зуміє він зібрати уламки геніальної епохи життя митця і скласти їх єдино правильним чином. В. Набоков до такого діалогу зі своїми читачами готовий. Заслуга B. Набокова в тому, що він не дає нам бути щасливими безбарвним, сірим життям, зануреними у сірі справи дня. Неодноразово митець звертається до читачів у своїх творах. У романі „Відчай” герой висловлює думку про те, що вища мета письменника: перетворити читача на глядача. У „Лекції 1958 р.” В. Набоков стверджує, що читачі народжуються вільними і повинні вільними залишатися.

Набоковська модель взаємин автора з читачем, зрозуміло, зумовлена тогочасною культурою модернізму, що передбачала насамперед наявність освіченого читача-інтелектуала. Отож, ці взаємини між автором і читачем мали стати відкритим діалогом, у якому читач міг би виступати у ролі співучасника естетичної гритворення нової реальності, а це, своєю чергою, мало сприяти творчому, неординарному розвитку людини.

Досліджуючи взаємини В.Набокова із сучасним йому читачем, Г. Рилькова зазначає, що неодноразово редактори журналів, до яких писав Набоков (зокрема журнал „Нью-Йоркер” і його редактор Катарін Уайт) зверталися до нього з проханням згадати про масового читача і почати писати простіше, адже навіть той, хто ніколи не читав 
В. Набокова, неодноразово чув про його незвичайність i „жорстокість” до простого читача. У цьому, безперечно, винен міф, створений Набоковим, який неодноразово публічно підкреслював власну байдужість до сторонньої думки і у житті, i в романах. Наведемо для прикладу цитату 3 „Дару”: „Настоящему писателю должно быть наплевать на всех читателей, кроме одного: будущего, который, в свою очередь, лишь отражение автора во времени" [12, т. 3, с. 305]. (Але Набоков все ж турбувався про масового читача, свідченням чого $\epsilon$ той факт, що він продовжував писати і давати інтерв'ю популярним на той час часописам).

Він присвячував свої твори читачеві майбутнього: „Мої книги, усі мої книги, призначені не для „тупаків”, не для ідіотів, упевнених у тому, що я обожнюю довгі латинізми, не для напіврозумних учених, які вишукують у моїх творах сексуальні чи релігійні алегорії: ні, мої книги призначені для Оміра ван Б., для моєї сім'ї, для декотрих інтелігентних друзів і для всіх, що схожі на мене, в яких би „розщілинах” нашого світу вони не знаходились - від бібліотечних кабінок Америки до похмурих прірв Росії" [8, с. 597]. В інтерв'ю для німецького телебачення 1971 року він зізнався: „Якщо по правді, я вірю, що одного чудового дня з'явиться новий поціновувач i повідомить, що я був зовсім не фривольним птахом у яскравому пір'ї (значення його псевдоніму Сірін. - Т. Ч.), а строгим моралістом, гонителем гріха, що відпускав ляпаси тупості, що висміював жорстокість та брутальність - і вважав, що тільки ніжності, талантові та гордості належить верховна влада" [8, с. 617]. Розмаїтість відгуків - це найкраща похвала для автора, - вважав В. Набоков, - і чим їх більше, тим краще.

Чи готовий до цих випробувань читач - сучасник В. Набокова? Не завжди. Звідси й виникали невдоволені голоси літературної критики на адресу письменника. Часто нарікали на певну його егоїстичність і навіть антигуманність щодо героїв і читачів, котрі виховані на гуманності літератури минулого століття.

Інтелектуальна гра В. Набокова як спосіб діалогічних взаємин 3 героєм і читачем була занадто новою і незвичною для російського культурного типу літературної рецепції, яка базувалася на звичці до готових, „розшифрованих” моделей світу і людини, представлених у художньому світі твору, і для широкого американського загалу, мало знайомого з В. Набоковим. Чи не тому він іде на унікальний крок: широко рекламує власну біографію російського емігранта у 
популярних виданнях, завдяки чому стає відомим одночасно з тим, як стає популярним. Це не лише стимулює інтерес читачів до письменника, але й підкреслює різницю між ним і його персонажами.

Гадаємо, запевнення про байдужість до свого читача у В. Набокова $\epsilon$ радше пересторогою перед „чужою свідомістю випадкового читача". І це можна пояснити, якщо згадати слова Хосе Ортега-і-Гассета: „Співіснування душ розкриває себе крок за кроком, душа відкриває своє потаємне іншій душі, і так далі; так спілкуються між собою серця" [13, с. 112], хоча з Набоковим ми скоріше спілкуємося на рівні інтелектуальному, аніж емоційному, а отже, дозволимо собі продовжити думку філософа: свідомість автора ділиться своїм інтелектуальним надбанням зі свідомістю читача. Чи $є$ для автора щось образливіше і нестерпніше, ніж неуважна публіка, яка позбавляє художнє спілкування всілякого сенсу й породжує брутальність (найненависнішу для В. Набокова рису людського характеру i способу життя)? Ми цілком погоджуємося з міркуваннями О. Червінської про те, що мистецтво завжди твориться для інших, бо його сутність полягає у тому, що одна людина створює для інших людей певну художню медитацію, яка розкриває їм природу Бога, світу і людей. Тому мистецтво потребує живої духовної зустрічі людей, коли один дає, а інший бере. I якщо ця зустріч не відбувається, у нашому контексті, - якщо не відбувається діалог „автора - героя - читача”, то мистецтво не здійснює свого призначення: читач не сприйняв, холодно відвернувся чи спотворив його значення, - письменник залишається незрозумілим і самотнім. Мабуть, тому так часто митці, у тому числі й В. Набоков, наголошують на своїй окремішності, „самості” у сучасному супільстві, яке їх не розуміє. Мистецтво відбувається тільки тоді, коли читач приймає і відтворює у своїй свідомості, уяві і душі творіння автора.

Отож, якщо читання - це спілкування, то природно, що співрозмовники мають сприймати думки одне одного, погоджуючись з ними або повністю заперечуючи їх. I тільки діалог $€$ гарантом толерантності та взаємоповаги у цій „розмові свідомостей” і „спілкуванні душ”. Тому звинувачення у примітивності чи елітарності того чи іншого автора за таких умов будуть недоречними. Кожен має право розраховувати на „свого” читача. I коли, наприклад, В. Набокова звинувачують в елітарності як у вияві неповаги до читача, це видається необ'єктивним і 
безпідставним. Специфіка сприйняття творчої особистості В. Набокова та його літературної спадщини закладена у тому, що первинним у діалозі 3 ним $є$ діалог свідомостей та інтелектів. Письменник-інтелектуал не вважав за потрібне пристосовуватись до посереднього читача. I це вже справа читача, чи він зможе піднятися на рівень „набоковського” читача, щоб бути гідним співрозмовником. Первинним для нього (читача) у процесі художньої комунікації $€$ визначення свого читацького характеру. Саме тут починається відмінність між читанням „народного” чи „елітарного” твору. Читач стоїть перед вибором: легке чтиво чи процес самовдосконалення, неможливий без постійної праці над собою. I якщо він згідний на плідну працю, то він готовий стати „елітарним” читачем, тобто „невипадковим”, „істинним” читачем. Саме у цьому основна заслуга елітарного письменника, зорієнтованого на вдосконалення людини, а не на пасивного споживача. Безперечно, Набоков є творцем із сильно вираженою авторською волею, і саме він керує розмовою, але і це природно пояснюється, якщо творчість розуміти як „спілкування сердець”.

На основі власних досліджень видається можливим систематизувати та проаналізувати тип читача у творах В. Набокова:

- наївний („Пам'яте, говори”): читач малообізнаний, відкритий на поверхневе розуміння тексту, не здатний до пошуків підтексту, непідготовлений до діалогу з автором, що може бути наслідком як вікових, так і соціальних, особистісних характеристик реципієнта;

- читач-турист (Передмова до роману „Bend Sinister”): байдужий читач, який бачить тільки те, що на поверхні. Продуктивність такого діалогу буде залежати від бажання реципієнта прийняти чи заперечити умови комунікативної гри;

- поважний [<Рец. на:> „Современные записки”. XXXVII] - читач з усталеними поглядами на літературу та власними міркуваннями щодо умов реалізації художньої комунікації. У такому випадку діалог нерідко перетворюється на монолог: реципієнт отримує тільки те, що вважає для себе за потрібне;

- звичайний [<Рец. на:> „Современные записки”. XXXVII] читач, котрий сумлінно дочитує книгу, навіть якщо вона для нього нецікава, що, на жаль, не гарантує плідного діалогу; 
- посередній („Пам'яте, говори”) - читач, котрий не читає усієї книги, відчуваючи небажання чи неспроможність вести діалог 3 автором.

Шанси стати „набоковським” читачем залишаються тільки для „розумного” і „невипадкового” [Передмова до роману „Запрошення на страту"] читача.

I що ж очікує цього „істинного читача”? Про це говорить сам автор у романі „Пам'яте, говори”: „...и наконец, достижение простого ключа награждает его синтезом пронзительного художественного наслаждения" [8, с. 569]. В одному з інтерв'ю В. Набокова запитали: „А насолода творчістю?” На що він відповів: „Вона уповні відповідає насолодам читання, блаженство, насолоду фразою поділяють письменник і читач: задоволений письменник і вдячний читач, або що одне й те саме - митець, вдячний невідомій силі у своїй свідомості, що навіяла йому комбінацію образів, і творчий читач, котрому ця комбінація принесе задоволення" [8, с. 164].

Бачимо, що автор, якого неодноразово звинувачували у повній байдужості до читацької аудиторії, усе ж поціновував читача, свого читача - творчого і вдячного. Мабуть, саме з цих вимог потрібно виходити, беручись до „вивчення” набоковської мови: слід замислитись, що означає творчий і вдячний читач для автора?

Цю думку простежуємо і в статті Г. Левінтона „The Importance of Being Russian...”: „<..> принцип відсилань, неявних контекстних зв'язків, „перегуків”, автоцитат, розрахованих на уважного читача („співбесідника”). Варто вдивитися у цю ситуацію, аби зрозуміти, що той „читач невіглас”, котрого дражнить В.Набоков <...> це усього лише неуважний читач" [4, с. 322-323]. Повністю погоджуємося 3 Г.Левінтоном у тому, що пізнати і зрозуміти набоковський світ можливо лише за умови, що уважний та інтелектуальний читач повністю ознайомлений з усією творчістю письменника і 3 його біографією в цілому, інакше гармонія і розуміння не відбудуться. У цьому переконують нас і герої його творів, особливо ті, яким він дарує особисті спогади і дає імена-анаграми, що говорять про самого Набокова, як, наприклад, Мак Наб у романі „Смотри на арлекинов” це герой „СНА”, тому справжня розмова може відбутися лише між читачем і самим Набоковим, але не з його героєм.

Пізнавальними в окресі досліджуваної проблеми є роздуми Ольги Червінської, котра пише: „Так званий "горизонт очікування” ліричного тексту і епіки - це принципово дві різні речі, тому що 
ліричний текст приковує нас до особистості Автора, тобто беззастережно, якнайбільше підкорює нас його образові і його волі, буквально змушуючи вступати у діалог саме з ним, тим часом як епіка дає нам право діалогізувати передовсім 3 персонажами" [16, с. 59]. Саме до такого типу „ліричного роману” зараховує Ольга Червінська романи В. Набокова, і ми з цим цілком погоджуємося, тому що набоковський читач веде свій діалог саме із „всемогутнім автором", і аж ніяк - не з його героєм. У цьому випадку правила гри диктує сам автор. Оскільки В. Набоков пише по-новому, ігноруючи всі літературні норми, обмеження і традиції, так і читачеві, щоб зрозуміти набоковський світ, необхідно вивчати його мову.

Для того, щоб відбулась розмова читача з В. Набоковим, першою умовою $є$ бажання читача розпочати інтелектуальний діалог-гру, обрану В. Набоковим. Друга умова: тон гри задає один Всемогутній Автор, а далі вже як у грі в шахи - все залежить від уміння і можливості гравців вирішити шахове завдання, створене автором.

Автор, як у шаховій грі (улюбленій грі В. Набокова), дає можливість іншому зробити свій хід: „Прощай же, книга! Для видений - отсрочки смертной тоже нет. С колен поднимается Евгений, - но удаляется поэт. И все же слух не может сразу расстаться с музыкой, рассказу дать замереть... Судьба сама ещё звенит, - и для ума внимательного нет границы - там, где поставил точку я: продлённый призрак бытия синеет за чертой страницы, как завтрашние облака, - и не кончается строка...” [12, т. 3, с. 480]. Автор надає "шанс" „уважному розуму” читача: авторське слово звучить і продовжується там і тоді, де і коли автора вже немає - він свідомо віддаляється, залишаючи право вибору за реципієнтом. Отож, у В. Набокова маємо таку „схему” взаємин „автор герой - читач": текст - герой (підвладний автору) - авторський оповідач (яким керує В.Набоков) - Твір (як вища сутність для В. Набокова) - набоковський читач 3 „уважним розумом”, для якого набоковський твір є запрошенням до діалогу. Тому діалог стає єдино можливою формою спілкування автора 3 читачем, що гарантує взаємоповагу та розуміння, яке базується на відповідальності особистості за свій вибір. Ця форма спілкування найбільш природна для письменників-інтелектуалів, якими переважно і $\epsilon$ елітарні письменники, зокрема Володимир Набоков.

Співтворчість автора з читачем передбачається вже в передмові до твору, (передмова - важлива частина набоковських романів). Докладно охарактеризувала цю проблему В. Мєдвєдєва-Гнатко: 
„Рефлектуючий автор цілком чітко усвідомлює, що спілкування 3 „чужим” читачем, 3 тим, хто, за визначенням 3 „Опалого листя” В. Розанова, „зменшує душу, а не збільшує”, може стати згубним у кризовій естетичній ситуації. Передмова покликана вберегти твір від попередньо чужих читацьких настанов, виявляючись нічим іншим, як авторським зізнанням у рефлексії” [6, с. 159]. Це положення знаходить підтверждення і в передмовах до романів В. Набокова. Наведемо декілька прикладів:

- „У передмовах, які я в останні роки писав до англомовних видань моїх російських романів, <..> я взяв за правило адресувати кілька заохочувальних слів віденській делегації” [9, с. 54]. Усі, хто хоча б побіжно ознайомлений з творчими поглядами В. Набокова, знають його „любов” до різношерстих психоаналітиків на чолі 3 Фройдом. Майже у кожній передмові Набоков попереджує читачів, що у випадку, якщо їх цікавить психологія чи політика, глобальні проблеми чи великі ідеї, то в його книгах вони цього не знайдуть.

- „”Despair” [„Отчаяние”] - споріднена всім моїм книгам - ні в чому не відповідає на соціальні запити сучасності, не містить жодної істини, котру могла би <...> донести до читача. Не справляє вона і величної дії на духовний орган людини, як і не вказує людству правильного шляху. У ній набагато менше „ідей”, аніж в цих наваристих вульгарних романах <..>. Спокусливої форми предмет чи сон по-віденськи, котрий палкий фройдист, як може йому здатися, віднайде на далеких звалищах моїх пустирищ, виявиться при ближчому розгляді глузливим міражем, підлаштованим моєю агентурою. Дозволю собі - на всяк випадок - додати для спеціалістів з літературних „шкіл”: з їхнього боку було б цілком розумно не намагатися в цьому випадку приплести між іншим „вплив німецьких імпресіоністів" [9, с. 60].

- „Я хотів би зекономити час і сили літературних „поденників” і взагалі осіб, котрі під час читання рухають губами і навряд чи зможуть прочитати роман, у якому нема діалогів, коли стільки корисного можна набрати із передмови до нього, - скерувавши їх увагу на першу появу теми" [9, с. 53].

Як бачимо, В. Набоков відвертий зі своїми читачами. Захищаючи себе від чужої і ворожої для нього свідомості випадкового читача, він водночас встановлює миттєвий контакт зі своїм читачем, даючи йому настанову вже в передмові до романів. I саме численні передмови ще раз свідчать про турботу В. Набокова про своїх 
читачів, адже ці романні преамбули є безпосереднім контактом автора зі своїми читачами. Саме у них В. Набоков привчає читачів звертатися 3 питаннями стосовно його життя і творчості безпосередньо до самого автора.

Цікаво, що розповідь майже в усіх російськомовних романах ведеться від третьої особи, це забезпечує об'єктивний погляд на події у романі, а майже всі англійськомовні романи викладені суб’єктивно, як і належить автобіографічній прозі. Від зміни особи оповідача, на нашу думку, змінюються і стосунки В. Набокова 3 читачем та героєм: третя особа оповідача робить читача (скористаємось набоковським словом) обсерватором („соглядатаем”) подій у романі; в іншому випадку вектор читацької уваги оманливо скеровується на першу особу оповідача, сприймаючи іï за альтер-его автора, що, своєю чергою, робить читача „спів-переживачем” подій у романі, тобто створює ситуацію ідентифікації читача 3 оповідачем. Останнє можливе за умови щирого діалогу. У якій із цих ситуацій читач буде найбільше наближеним до автора-Набокова? Це, безперечно, залежатиме від читацького характеру. I все ж у будь-якому випадку треба пам'ятати про естетичні позиції В. Набокова у словесному мистецтві, а тому не приймати змальоване уявою за реальність.

Важливим $\epsilon$ i той факт, що майже всі свої твори В.Набоков присвячував своїй дружині Вірі, що у текстах проявляється в інтимному звертанні до „ти”, до приятеля-дружини, а пізніше і до сина. В останніх творах В. Набокова ці звертання організовують гармонійний, єдиний і неподільний всесвіт, наповнений любов'ю і вірою.

В. Набоков, стверджуючи право на верховенство ніжності, краси, правди і гармонії, знищує брехню, грубість, жорстокість, лицемірство й усе „псевдо": втілюючи їх у своїх романах, висміюючи їх, веде до очищення. Він упевнений, що істину не можна проповідувати, її можна шукати і відкривати. Подібно до Сократа, який шукав істину в діалогах, Набоков шукає її і дає можливість знайти її читачеві у діалозі з ним через посередництво роману. Ані час, ані простір у цьому випадку не мають значення, тому що вони безсилі перед силою таланту й інтелекту, а також перед близькістю душ і свідомостей співбесідників.

В останньому романі „Пам'яте, говори” герой, волею автора найбільш наближений до нього, висловлює таку думку: „следует понимать, что соревнование в шахматных задачах происходили не между белыми и черными, а между составителем и воображаемым 
разгадчиком (подобно тому, как в первоклассных произведениях писательского искусства настоящая борьба ведется не между героями романа, а между романистом и читателем..." [8, с. 567]. А оскільки В. Набоков - це письменник-інтелектуал, то, природно, що єдиною формою цієї боротьби буде діалог.

Як відомо, будь-який твір мистецтва створюється людиною для людини і про людину, а отже, $є$ антропоцентричним у своєму зародженні та існуванні. Тому, безперечно, наша розмова про антропологічну сутність творів буде неповною, якщо ми не згадаємо ще про одного учасника літературного діалогу - про героя художнього твору.

У інтерв'ю В. Набокова Альфредові Аппелю на репліку про те, що багато авторів визнають, що герої оволодівають ними і деколи диктують подальший розвиток сюжету, Набоков дав категоричну відповідь: „Ні, задум роману міцно тримається у моїй свідомості, і кожний герой іде тим шляхом, який я для нього вторував. У цьому приватному світі я абсолютний диктатор, і за його істинність і міцність відповідаю лише я" [1, с. 168]. У своїх інтерв'ю В. Набоков неодноразово наголошував, що всі його персонажі - „галерні раби”, маріонетки, які ніколи не виходять 3-під контролю і повністю підвладні всемогутньому авторові.

Погоджуємося, що обрана В. Набоковим оповідна стратегія не сприяє ідентифікації героя 3 письменником, а читача 3 героєм. Спостерігаючи за його героями, нам часто здається, що перед нами лише „життєподібні”, чудово вимальовані маски у виставі, котру розігрує невидимий, але всемогутній автор.

Та пильний читач має зауважити, що романи В. Набокова є часто незакінченими, а доля їх героїв, як, наприклад, Мартина у „Подвизі”, або Федора Годунова-Чердинцева у „Дарі” тощо невизначена, тобто потребує читацької „співучасті”.

Часто головний герой непомітно для себе самого стає маріонеткою, якою рухає добра чи зла, але чужа воля, втягується у гру, правила якої задані автором. Підтвердженням цього слугують слова М. Цетлін: „Велике поширення отримала [у В. Набокова] „концепція героїв-манекенів”, якою Сірін ”показує механічність, автоматизм сучасних людей”, своєрідних роботів, „у них нема ані любові, ані пристрасті”, усі їх почуття „обездушені”, позбавлені „людяності” [Див.: 9, с. 218-219]. Герої В. Набокова дійсно нагадують нам ляльок, і це випливає з таких факторів: 1) лялька стає носієм ідеї 
„механістичності” і самого героя, і його долі, адже нею керує чужа воля; 2) з образом ляльки пов'язана ідея гри; 3) тема лялькового царства наводить на думку про фантастичність або ж фальшивість зображуваного світу; 4) ця тема дає можливість автору зайняти щодо створюваного ним світу позицію „позазнаходження”, остання організовує дистанцію між автором і героєм.

Усі щойно згадані риси знайдемо у таких творах В. Набокова, як „Запрошення на страту”, „Король. Дама. Валет”, „Захист Лужина”.

Цікавим для нас $є$ ще одне інтерв'ю В. Набокова, яке він дав А. Сєдих. Письменника запитали, чому у фізично і морально здорової, спортивної людини всі герої такі схибнуті люди? На це він відповів: „Схибнуті люди?.. Так, можливо. Ви маєте рацію. Важко це пояснити. Здається, що у стражданнях людини є більше значного і цікавого, аніж у спокійному житті. Людська натура розкривається повніше. <..>> Автор у процесі роботи ніколи не ототожнює себе 3 головним діючим персонажем роману, його герой живе самостійним, незалежним життям; у цьому житті все наперед передбачено, і ніхто вже не може змінити його розміреного ходу. <...> Честь і слава письменнику, герої якого здаються людьми, які живуть серед нас, нашим повсякденним життям" [10, с. 146-147].

На нашу думку, герой В. Набокова більше наближений до героя екзистенціалізму: увага зосереджується на індивідуальному самовираженні людини, особливо якщо це людина XX ст., яка відчуває повну абсурдність реального світу і тому незадоволена, відчужена, часто перебуває у відчаї. Саме відчуття неспокою, відчаю i незадоволення, загрози смерті ведуть до самоаналізу, який може завершитися висновком про потребу самореалізації. Для повного осягнення справжнього сенсу свого існування у філософії екзистенціалізму людина повинна пройти такі етапи: етап відчуття вкинутості у цей світ і своєї покинутості у ньому, етап „межової ситуації" - усвідомлення конфлікту зі світом та свого невдоволення, що й приводить до самоаналізу, пізнання та вибору власних життєвих вартостей і етап вільного та свідомого вибору дотримування цих вартостей у своєму житті. Тільки свобода людини та свобода вибору дають їй змогу самовиявитися і надати сенс своєму існуванню. Водночас такий вибір пов'язується із відповідальністю перед собою та перед іншими. Намагання досягнути своєї автентичності - основна мета у житті, бо людська екзистенція має сенс тоді, коли людина обирає власні можливості і відповідає за результати вільного вибору 
і власної свободи. Індивідуальність, сутність, суб'єктивність, свобода, смерть - це основні теми екзистенціалізму, які знаходять своє вираження й у творчості Набокова, отримуючи своє нове втілення, зумовлене чинником гри.

Як відомо, читач більше проймається довірою до героя, якщо оповідь ведеться від першої особи, через що може втратити об'єктивність сприйняття решти художнього світу. Автор-Набоков завжди займає стосовно світу твору позицію „зверху”. У такий спосіб автор коригує і читацьке сприйняття, змінюючи особу оповідача. Та саме в цій зміні і виявляється авторська гра з читачем: різноманітні ракурси бачення завжди перекриваються особистістю автора, іноді збігаючись 3 одним із героїв (їхні взаємини нагадують діалог Пушкіна з Онегіним), але в результаті „цілосукупність” героя завжди залежить від ступеня наближення до „я" В. Набокова.

Характерним для В. Набокова прийомом $є$ оманлива подібність біографічних фактів героїв до фактів його власної біографії. Однак цю подібність уважний читач простежує лише на поверхні. Як же сприймає Набоков-автор створених ним персонажів?

Стосовно свого першого роману „Машенька” В. Набоков зізнається: „Добре відома схильність автора-початківця втручатися у своє особисте життя, виводячи себе чи свого представника у першому романі, пояснюється не стільки спокусою готової теми, скільки почуттям полегшення, коли, відмежувавшись від самого себе, маєш можливість перейти до більш цікавих предметів. Це одне з дуже небагатьох загальних правил, яке я прийняв. <...>. Його (Ганіна) Машенька і моя Тамара - сестри-близнята; тут і дідівські паркові алеї" [9, с. 67]. Та Машенька є сестрою-близнючкою не тільки Тамари, але й усієї Росії - першої любові Набокова, що з нею він прощається у цьому романі.

Про Лужина В. Набоков говорить, що насправді Лужина полюбили навіть ті, хто зовсім не розуміється на шахах і відчуває відразу до решти набоковських книг: „Він незграбний, неохайний, некрасивий зате, як дуже швидко підмітить моя ніжна панночка (по-своєму чудова дівчина), у ньому $є$ щось, що перевершує і грубість його сірої плоті, і безплідність його темного генія. <...>. Я подарував Лужину мою французьку гувернантку, мої кишенькові шахи, мій чудовий характер i кісточку від персика, якого я зірвав у своєму відгородженому садку" [9, с. 54-55]. Із власного минулого В. Набоков 
уводить у фіктивний світ свого роману ще одного персонажа - Розена, прототипом якого є однокласник автора С. Розов.

Про героя „Подвигу” - романного двійника автора (так називає його критика) - В. Набоков говорить, що Мартин - добрий, чесний і найзворушливіший 3 його героїв: „...Мартина ще можна якоюсь мірою вважати моїм далеким родичем (він симпатичніший за мене, але й набагато наївніший, ніж я коли-небудь був), з яким у мене $\epsilon$ декілька спільних дитячих спогадів <...>, а його бліді батьки <...> не подібні до моїх... Що стосується кембріджських приятелів, Мартин та Дарвін повністю придумані, так само Мун, а от „Вадим” і „Тедді” реально існували у моєму власному кембріджському минулому <...>. Герой „Подвигу”, до речі, не обов язково цікавиться політикою - це перший 3 двох фокусів чарівника, який створив Мартина (виділено нами. - Т. Ч.). Здійснення - це фугова деталь його долі; він 3 тих небагатьох людей, чиї „сни” збуваються <...>. Мій другий помах чарівної палички такий: до багатства дарів, якими я щедро наділив Мартина, я зумисне не додав таланту. Як було б легко зробити його художником, письменником, як важко було не дозволити йому цього, нагороджуючи його при цьому тією тонкою чутливістю, яку зазвичай асоціюють з творчою особистістю, як жорстоко не дозволити йому знайти у мистецтві - ні, не „притулок” (тому що це всього лише чистіша камера на тихішому поверсі), але перепочинок від свербежу буття! Верх узяла спокуса звершити мій особистий маленький подвиг у сяйві всемогутності. Результат нагадує мені шахове завдання, яке я колись створив. Його чарівність у парадоксальному першому ході: білий ферзь має чотири вільних клітинки у своєму розпорядженні, та на будь-якій з них він буде заважати (така сильна фігура - і „заважати”!) одному з білих коней у чотирьох варіантах мата; іншими словами, будучи зовсім беззмістовним і шкідливим тягарем на дошці, не граючи жодної ролі у подальшому розвитку партії, він повинен піти у вигнання у нейтральний куток, позаду смертного пішака й перебувати там у бездіяльності і без відома" [12, с. 72-74]. Таким чином, автор постійно наголошує на дистанції, яка існує між ним та його героєм. Із власного минулого В. Набоков уводить у роман епізодичного героя - Іоголевича - прототипом якого $\epsilon$ Лазар Іоголевич, однокласник брата В. Набокова - Сергія.

У передмові до англійського перекладу роману „Король. Дама. Валет” В.Набоков дає йому таку характеристику: „Російський 
письменник, добираючи виключно німецьких персонажів (ми 3 дружиною з'являємося у двох останніх главах тільки для інспекції), створює для себе нездоланні труднощі. <...> герої-емігранти, котрих я виставив напоказ у вітрині, були до того примарні на погляд тієї епохи, що позаду них можна було легко розгледіти ярлички з їх описом, на щастя, надписи були не досить розбірливі, та у мене не було жодного бажання продовжувати користуватися методом, характерним для французькому різновиду "людського документа", де ізольовану групу людей достеменно відображає один з її членів" [9, с. 64].

Часто критики називають героя „Дару” „alter-ego” В. Набокова. Щодо цієї думки, Набоков зауважує: те, що вони з героєм одночасно жили в Берліні і мали спільні інтереси, не дає підстав прирівнювати художника і малюнок: „Я не Федір Годунов-Чердинцев і ніколи ним не був, мій батько не дослідник Центральної Азії, яким я, можливо, коли-небудь стану. Я не залицявся до Зіни Мєрц і не був стурбований думкою поета Кончеєва чи будь-якого іншого письменника. Якраз радше у Кончеєві та в іншому епізодичному персонажі - романісті Владимирові - я впізнаю деякі уламки самого себе, яким я був десь у 25-му віці” [9, с. 49-50]. Із інтерв’ю: „Федір це не я. Я намагаюся тримати моїх персонажів поза межами моєї особистості. Тільки про тло роману можна сказати, що воно містить деякі біографічні штрихи. <..> Деякі мої персонажі, без сумніву, страшенно гидкі, та мені насправді все байдуже, вони поза межами мого я, як похмурі монстри на фасаді собору - демони, розташовані там тільки тому, щоб показати, що вони звідти вигнані. Насправді, я тихий, старий пан, котрий ненавидить жорстокість" [9, с. 143; 146]. Та, читаючи листи В. Набокова до Самуїла Розова [Див.: 10, с. 12-33], можна зауважити, що автор подає йому власні спогади про дитинство майже без змін. Із тих самих листів дізнаємося, що Набоков любив зустрічати власне минуле тільки у своїй прозі, тому що бажання повернути його у реальності завершилося тим, що, цитуємо В.Набокова, „Я цим вбив наповал свої кембріджські спогади" [10, с. 19].

В. Набоков називає головною темою „Bend Sinister” „биття люблячого серця Круга, муку напруженої ніжності, що роздирає його" (і саме заради цих сторінок, присвячених Давидові і його батькові, була написана ця книга, і заради них, уважає автор, їі треба прочитати); і тема благословенного божевілля Круга, коли він раптом сприймає просту сутність речей і розуміє, але не може 
висловити у словах цього світу, що і він, і його син, і жінка, і всі решта - всього лише примхи та витівки автора: „Тому <...> з'являється перший натяк на когось, „кто в курсе этих дел,” - на загадкового самозванця, що використовує сон Круга для передачі особистого химерного тайнописного сповіщення. Цей самозванець - не віденський шарлатан <..>, а антропоморфне божество, зображене мною. В останньому розділі книги це божество відчуває укол співчуття до свого творіння i поспішає втрутитись. Круг у раптовому місячному спалахові божевілля розуміє, що він у надійних руках: ніщо земне не має реального смислу, боятися немає чого, і смерть - це всього лише питання стилю, простий літературний прийом, розв'язання музичної теми. <..> втішений Круг повертається у лоно свого творця " [9, с. 81].

„Мої персонажі, - говорить В. Набоков про цей роман, - не „типи”, не носії „ідеї” < ...> Всі вони є лише безглуздими міражами й ілюзіями, що пригнічують Круга, поки він недовго перебуває під чарами буття, і без шкоди розсипаються, коли я розпускаю трупу” [9, с. 77].

„Люди у цій книзі, - скаже про героїв „Спостерігача” ("Соглядатая") В. Набоков, - улюблені персонажі моєї літературної юності: російські вигнанці, що мешкають у Берліні, Парижі чи Лондоні..." [9, с. 56].

Суттєвим для характеристики цього роману буде порівняння етичної системи В. Набокова 3 „Монадологією” Лейбніца [Див.: 5, с. 619-649]. Відомо, що Набокова неодноразово звинувачували у тому, ніби він зображує не живих людей, а персонажів-маріонеток, якими керує чужа воля. Дії героїв здаються запрограмованими, бо їхній світ організований так, що його події лише їм самим здаються зумовленими їхніми бажанням і їхнім вибором, але читач знає, що вони $є$ результатом загального плану. Чи є різниця між монадою і роботом? Подібність між ними у тому, що їхнє майбутнє приречене. Робот не має жодної надії на свободу вибору, адже у нього є конкретна програма, згідно з якою він мусить діяти. Монада ж, у певному нетривіальному розумінні, $є$ вільною. Ї̈̈ буття володіє виміром спонтанного самовизначення. Хай ї̈ майбутнє приречене - воно відноситься до буття монади інакше, аніж програма до буття робота. Доля не смикає за ниточки, а проживається вільно. Чи можуть співіснувати приреченість i свобода? Література, як її називає Г. Хасин - це такий спосіб, коли це співіснування можливе $[15$, с. 644]. Читаючи книгу, ми знаємо, що 
вона вже цілком написана, а отже, доля всіх героїв визначена до того, як вони почнуть діяти. Попри те, навіть перечитуючи книгу, ми можемо сприймати їх вільними і відповідальними за свої вчинки.

Автора у такому розрізі ми можемо порівняти з Богом, а героїв - 3 монадами. Г. Лейбніц уважає, що Божественне зусилля є зусиллям гармонізації, а не примусової влади. Щоб постійно не змушувати речі відповідати своїм задумам, Бог просто створює їх так, щоб, вільно реалізуючи свою природу, вони у поєднанні утворювали максимально довершене ціле. Приреченість здійснюється через природну спонтанність індивідуумів. Таке використання свободи для реалізації передбаченого порядку зумовлює специфічні стосунки між вільним агентом та його майбутнім. Якщо ми вільні і якщо майбутнє вже існує, то ми не можемо ані знати його, ані запобігти йому. Отож, у контексті свободи приреченість функціонує не як програма - вона набуває форми Долі. Тому щодо героїв В. Набокова авторське ставлення аналогічне до ролі долі. Що ж до автора-Набокова, то його герої співвідносяться з монадами Лейбніца.

Підводячи підсумки, які дозволяє зробити метафізика „Монадології”, зауважимо, що визначенню Г. Лейбніцом Блага як Довершеності загалом відповідає етична система Набокова. Мистецтво у такій системі стає вищою цінністю, бо довершеність $€$ основою для існування всього сущого - і в природі, і в культурі.

Надзвичайно важливим у контексті нашого дослідження $є$ есе В. Набокова „Про хороших читачів і хороших письменників”, у якому йде мова про постаті автора і читача та їх роль у створенні художніх світів. В. Набоков уважає, що книгу взагалі не можна читати, їі можна тільки перечитувати. Хороший читач, читач вибірковий, співучасник і співтворець - це перечитувач, з розвиненою уявою та пам'яттю, багатим словником і художнім смаком, який повинен зауважувати дрібниці і милуватися ними, адже він стає свідком створення нового світу - світу художнього твору. Кожен великий роман - це казка: час і простір реального світу втрачають у ньому важливість. Автор творить його, піднімаючись невідомими стежками на вершину, де зустрічається зі щасливим, хоча i змученим читачем, який зумів подолати цю вершину. Щодо постаті письменника, В. Набоков зауважує: „Письменника можна оцінювати з трьох точок зору: як оповідача, як учителя, як чарівника. Усі троє оповідач, учитель, чарівник сходяться у великому письменникові, але великим він стане лише тоді, коли гру на першій скрипці 
відведено чарівникові" [11, с. 10]. До оповідача ми приходимо за новими враженнями, емоціями. До вчителя - за новими знаннями. Та найцікавіше, коли ми звертаємося до чарівника, - ми пізнаємо індивідуальну магію письменника, його стиль, образність, структуру його творів тощо. Для того, щоб поглинути в цю магію „для читача найбільше підходить поєднання художнього складу мислення з науковим. Безмірна художня пристрасть вносить зайву суб'єктивність у ставлення до книги, холодна наукова розсудливість охолоджує жар пристрасті. Однак, якщо майбутній читач взагалі позбавлений пристрасності і терплячості пристрасності художника і терплячості вченого - він навряд чи полюбить велику літературу" [там само].

Отже, для В. Набокова у діалозі „автор - герой - читач” важливим $\epsilon$ постать читача, від якої залежить життя героя художнього твору i реалізація самого твору. Головним $\epsilon$ той факт, що В. Набоков, якого звинувачували в ігноруванні і героя, і читача, у романі „Відчай” висловив таку думку: „Высшая мечта автора: превратить читателя в зрителя, - достигается ли это когда-нибудь? Бледные организмы литературных героев, питаясь под руководством автора, наливаются живой читательской кровью; гений писателя состоит в том, чтобы дать им способность ожить благодаря этому питанию и жить долго" [12, с. т. 3, 342], що є підтвердженням нашої думки щодо сутності літературного твору у діалозі „автор-герой-читач”.

\section{2. Утілення категорії-ідеї спілкування в художній діяльності автора - героя - читача}

„Мистецтво - це подія, яка відбувається в нас самих, коли ми споглядаємо картину чи читаємо книгу" [13, с. 228], - констатує Хосе Ортега-і-Гассет.

Мета кожного інтерпретатора - концептуально наблизитися до творчого „я" письменника. Починати вивчення художнього світу В. Набокова, оминувши при цьому його особистість, неможливо. Його твори не розраховані на непідготовленого читача, який, вперше ознайомившись 3 ними, просто їх не сприймає. Можливо, якщо ми змінимо „традиційний”, характерний, на жаль, у наш час хід знайомства з літературою: твір, а потім вже особа автора (та й це не завжди, адже сучасні книговидавці не вважають за потрібне подати навіть мізерну дещицю життєпису автора, бо сучасні читачі на неї не звертають жодної уваги) - i познайомимося спочатку 3 
неординарною особистістю автора (що ми й намагались зробити на попередніх сторінках роботи), то ми не будемо відчувати себе такими беззахисними, вступаючи у діалог зі світом художніх творів В. Набокова чи будь-якого іншого письменника.

Для об єктивної інтерпретації художнього твору, на нашу думку, слід вважати як на позатекстові, так і на текстові фактори дослідження образу автора. До позатекстових факторів відносимо світогляд, факти біографії, конкретні соціально-історичні умови творчості, суспільну ідеологію, індивідуально-психологічні особливості творчої особистості письменника, „модель читача”. До текстових - авторський стиль та безпосередньо „модель автора” зокрема у конкретному творі й у фоні усієї його творчості.

Отже, інтерпретатор відбудеться тільки тоді, коли він відбудеться як концептуальний читач, у чому ми й вбачаємо свою мету. Окреслимо основні шляхи інтерпретації, обрані нами для вивчення творчості Набокова:

1) авторська позиція і її превалювання над героєм;

2) шляхи становлення героя як смислового цілого на основі концепції творчості як гри у В. Набокова;

3) авторське ставлення, настанова, гра з читачем у В. Набокова (можливі „виходи” читача на діалог „автор - читач” без посередництва героя);

4) самодостатність художнього світу творів В.Набокова як потенційна енергія діалогу (індивідуально-авторський стиль як форма втілення творчого діалогу).

Для дослідження питання у такому його окресі звернемо особливу увагу на працю М. Димарського „Deus ex texto, чи Вторинна дискурсивність набоковської моделі наративу" [Див: 3, с. 236-260]. Науковець підкреслює, що у творчості В. Набокова спостерігаємо зрушення характеру локалізації автора у структурі тексту. Простежимо цей процес. До того моменту, поки локалізація автора у структурі тексту стабільна від його початку і до кінця, ми перебуваємо у річищі класичної традиції. Два основні різновиди цієї моделі (Я-герой і ВІН-герой; у термінах В. Падучевої - традиційні розповідні форми): 1) з дієгетичним оповідачем, що належить до світу тексту, інакше - першоособова форма; 2) з екзегетичним оповідачем, що не належить внутрішньому світові тексту, інакше аукторіальна форма, або ж наратив 3-ї особи - передбачають незмінність позиції оповідача як представника автора у тексті, і в 
цьому розумінні - стабільність локалізації автора. Якщо ж уводиться додаткова маска чи рамка (яка змінює локалізацію автора), тоді вони маркуються, і читачеві чітко дається зрозуміти, хто $€$ хто. Читач, своєю чергою, може скласти своє враження про створений автором світ, тільки спираючись на поданий у тексті початок відліку, яким $\epsilon$ „аналог мовця”, через призму якого ми сприймаємо цей світ. Окрім цього фактора, читачеві взагалі більше немає на що розраховувати, адже ані часові, ані просторові координати автора і читача не збігаються. Тому від характеру локалізації автора у тексті - від її стабільності чи нестабільності безпосередньо залежить можливість чи неможливість для читача побудувати несуперечливу і достатньо визначену модель художнього світу. Отож, читач „декодує” закладену у тексті модель „можливого світу” з позиції аналога мовця-оповідача.

Для читача дейктична визначеність дає можливість скласти несуперечливу картину зображеного „можливого світу”. Можна сказати, що у такому випадку має місце дейктичний паритет між автором і читачем: останній має змогу зазирати разом з автором у будь-який пункт художнього простору-часу; хронотоп не має замкнених для читача зон. Дейктична визначеність тексту i дейктичний паритет автора і читача - настільки суттєві ознаки класичного (традиційного) наративу, що їх дотримання дозволяє авторові іноді помилятися (іноді зумисно). У такому випадку від читача вимагаються додаткові зусилля, щоб зауважити ті „помилки”, ті порушення правил гри, яких авторові не вдалося оминути.

Модерністична оповідь зазвичай відмовляється надати читачеві безпосередні вказівки на потрібну інтерпретацію, вона моделює іншого читача, спроможного таку підказку знайти самостійно чи й додумати собі і таким чином отримати задоволення від тексту.

В. Набоков у своїх романах апелює до читацького досвіду, без якого важко стати саме набоковським читачем. Цей досвід має допомагати читачеві знаходити потрібні натяки для вірної інтерпретації. Непідготовленого до такого читання (коли автор пропонує читачеві створити нову реальність, разом змоделювати їі, згідно із запропонованими у самому тексті способами) цей епатажний вихід автора дивує і навіть лякає, адже нечасто у класичній літературі читач мав можливість бути співучасником створюваної художньої реальності. Саме тому у своїх творах В. Набоков часто змінює точку зору оповідача: це може бути точка 
зору стороннього спостерігача; позиція всезнаючого оповідача, ускладнена награною невпевненістю; позиція інших героїв або ж всемогутнього і всезнаючого Автора i, нарешті, внутрішня позиція самого героя. Та часто у фіналі набоковських творів читач доходить висновку, що всі ці точки зору були хибними, а істина випливає як випадковий факт, як післямова. Іншими словами, на очах читача будується світ оповіді, істинність якого у фіналі ставиться під сумнів, тому що для автора важливим $є$ не так цілісний завершений світ твору, як процес його побудови, в якому читача змушують бути не просто споживачем, а активним спостерігачем („обсерватором”). Так побудоване, наприклад, оповідання „Корольок” (про це докладно див.: 9, с. 237-260).

В оповіданні „Круг” читача зустрічає невизначена особа оповідача, представлена займенником „ми” - чи $є$ це „ми” авторським, чи, може, авторським і читацьким сукупно? Безперечно, що автор цим підкреслює власну присутність, як і численними вставними конструкціями. Отож, у тексті набоковських оповідань, на думку М. Димарського, перед нами постає деміург, який, по-перше, творить героя, його світ і життя; по-друге, уважно стежить за цим процесом і, по-третє, те і інше втілює у тексті. Тому сам процес творення стає головним змістом твору.

В. Набоков ніби скеровує увагу читача з тексту на сам процес читання. Тому при першому читанні більшість його романів та оповідань сприймаються легко. Однак, як зауважує Л. Токер [14, с. 377], почуття елітарної напівінтимності з автором значною мірою оманливе, і при першому читанні багато що залишається непобаченим і непочутим. Як говорив В. Набоков, романи не можна читати, їх можна тільки перечитувати. При повторному прочитанні ми не просто бачимо більше, але й сприймаємо й оцінюємо особистість і поведінку героїв якісно по-іншому, аніж перший раз. Отже, змінюємося і ми самі, адже нерідко наша оцінка стає протилежною, залежно від умов сприйняття цієї естетичної гри і нашої підготовленості до неї.

Божественний i деміургічний характер авторської сили $\epsilon$ популярною темою модерністичної літератури. Актуалізується ця тема і у творчості В. Набокова.

Один із сучасних набокознавців, американський учений Д. Бартон Джонсон, виокремлює у „естетичній космології” Набокова три світи: перший світ, нижчий, - це світ оповіді, світ героя. Те, що у 
ньому відбувається, - це лише відображення вищого світу автораоповідача, котрий, своєю чергою, зумовлений ще вищим, більш реальним, світом - світом самого Набокова. Ця теорія знаходить своє втілення і в теорії „текстів-матрьошок” Сергія Давидова [Див.: 2, с. 476-490]. Давидов вказує на діалог між Цинциннатом, автором „гностичної сповіді” і автором самого роману як на пізнання істинного „я” у його онтологічному сенсі.

Д. Бартон Джонсон зазначає, що велика частина прози Набокова виявляє у своїй основі космологію „двох світів”. Обидва світи уявні, але один відносно подібний до нашого, інший, часто відверто фантастичний, $є$ антисвітом. Кожен із цих світів може слугувати майданчиком для романної дії, але при цьому неподалік мерехтить образ іншого світу.

Тема прозорості реального світу в порівнянні 3 художньоетичним $\epsilon$ однією зі стрижневих у творчості В.Набокова, та найяскравіше своє висвітлення вона отримала у романах “Запрошення на страту", “Дар" та “Захист Лужина”. За словами Цинцинната Ц., головного героя роману “Запрошення на страту”, він живе в “сегодняшнем наскоро сколоченном и покрашенном мире" $[12$, т. 4, с. 28]. Злочин Цинцинната у тому, що він „...чужих лучей не пропуская, а потому в состоянии покоя, производя диковинное впечатление одинокого темного препятствия в этом мире прозрачных друг для дружки душ..." [12, т. 4, с. 12] є єдиною правдивою людиною. Свою непрозорість, а отже - істинність і неповторність, він отримав у спадок від батька, який, як і його син, за словами матері, був Цинциннатом (як і у випадку з Федором в „Дарі”, можемо ототожнити батька 3 автором). Цинцинната страчують у цьому ілюзорному світі: йому відрубують голову. Та саме цей факт фізичної смерті дарує йому свободу. Піднімаючись 3 місця страти, він бачить, що “зрители были совсем, совсем прозрачны, и уже никуда не годились, и все подавались куда-то, шарахаясь, - только задние нарисованные ряды оставались на месте. <...> Все расползалось. Все падало. Винтовой вихрь забирал и крутил пыль, тряпки, крашеные щепки, мелкие обломки позлащенного гипса, картонные кирпичи, афиши" [12, т. 4, c. 129,130$]$. Він знав, що „все это театральное, жалкое... Вот тупик тутошней жизни, и не в ее тесных пределах надо было искать спасения" [12, т. 4, с. 118$]$. 
Цинциннат Ц. після виконання вироку отримує істинну свободу, внутрішній спокій і гармонію (він відвернувся від катів і йде до натовпу, „своїх”, що зустрічають його), автор дарує йому можливість возз'єднатися з Творцем.

У більш загальному сенсі - це і два світи Цинцинната: внутрішній і зовнішній світи людського буття. На жаль, людська свідомість часто скута нормами людського існування у суспільстві, і тоді людина думає і висловлюється, а найпаче, діє проти своєї внутрішньої волі і цим і порушує свою внутрішню гармонію. У цьому вічна трагедія творчої натури. I в цьому перемога В. Набокова, котрого неодноразово звинувачували у егоїзмі через те, що він був вільний від суспільства і його законів і завжди керувався лише своїм внутрішнім законом.

Особливий інтерес у цьому романі викликає гра в нетки, про яку розповідає Цецилія Ц. Ця гра ніби відображає сутність того безглуздого світу, що з нього незабаром вирветься Цинциннат: „Одним словом, у вас было такое вот дикое зеркало и целая коллекция разных неток, то есть абсолютно нелепых предметов: всякие такие бесформенные, пестрые, в дырках, в пятнах, рябые, шишкованные штуки, вроде каких-то ископаемых, - но зеркало, которое обыкновенные предметы абсолютно искажало, теперь, значит <...> в нём <...> все получалось замечательно; нет на нет давало да, все восстанавливалось, все было хорошо <...> получался в зеркале чудный стройный образ. <...> Можно было - на заказ - даже собственный портрет, то есть вам давали какую-то кошмарную кашу, а это и были вы, но ключ от вас был у зеркала" [там само, с. 77]. Ключами від своїх героів володіє автор, котрий не бажає, щоби неуважна читацька свідомість витворювала з його героїв „жахливу кашу”.

Цинциннат намагається написати книгу, щоб цим актом творення подолати смерть. Та чим більше він намагається писати, тим меншим стає його олівець, тим менше залишається йому днів до страти. Але порятунок приходить від автора, який дає своєму герою зрозуміти, що він $\epsilon$ лише літературним героєм, отож він не може померти.

Цікаво поданий світ уяви героїв - як відбиток усіх таємниць реального світу в їх внутрішньому бутті. Здатністю до уяви, особливою проникливістю, особливою чутливістю до звуків і фарб, до метаморфоз природного і соціального буття наділені у Набокова тільки його, дозволимо собі сказати, „улюблені” герої. Але й увага до явищ феноменального світу, згідно з Набоковим, $\epsilon$ лише передумовою „правильного” пізнання і може обернутися на зло, якщо 
наділена нею людина не зробить наступного кроку і не усвідомить, що видима реальність у всьому їі розмаїтті $\epsilon$ тільки „театр земної звички, мундир тимчасового єства", під яким ховається таємниця, непідвладна глузду. Спасіння у Набокова отримують тільки ті герої, котрі можуть, як Федір, відчути „странность жизни, странность её волшебства, будто на миг она завернулась, и он увидел её необыкновенную подкладку" [12, т. 3, с. 164].

3 героями багатьох романів Набокова (Мартин - „Подвиг”, Годунов-Чердинцев - „Дар”, „Цинциннат Ц.” - „Запрошення на страту”) ми знайомимося під час їх вигнання: Мартина і Федора - 3 дитинства і Росії, Цинцинната - з гармонійного „непрозорого” світу минулого. Всіх їх об’єднує приналежність до втраченого раю: поперше, зв'язок з минулим (в якому не було всезагальної прозорості для Цинцинната; в якому залишився світ дитинства Мартина і Федора); по-друге, зв'язок з „там”, зв'язок з природою, постійною спільницею героїв Набокова (Тамарині сади як аналог раю для Цинцинната; необхідне спілкування з природою для Мартина i Федора, які відчувають себе невід'ємною часткою цієї природи); потретє, світ снів: для Цинцинната - „в снах <...> мир был облагорожен, одухотворён"; сон Федора про повернення батька; ігри і мандрування Мартина у снах. Часто події, що відбуваються в реальності, менш реальні, аніж сновидіння героїв, що часто вводить читача в оману. Один 3 ігрових прийомів Набокова полягає в особливому значенні снів в його останніх романах „СНА” („Смотри на арлекинов”), „Прозорі речі”.

Кілька слів про роман „Король. Дама. Валет”. Неодноразово у критиці підкреслювався автоматизм, механічність героїв, які через егоцентризм та обмеженість не могли насолоджуватися життям і по суті були манекенами, яких Драйєр замовив для своєї крамниці. Агентом автора у романі $є$, безперечно, фігура творця манекенів, яка асоціюється 3 самим Набоковим, для котрого його герої представляють собою свого роду манекенів, запрограмованих їх творцем на певні дії. Саме реальність 3 іï марнотою, автоматизованими, запрограмованими людьми наштовхнула Набокова на створення таких героїв.

Доля у творах Набокова завжди пов'язана із задумом самого автора, адже вона $є$ фактором авторської свідомості. Тому так часто у романах доля, випадок грається з персонажами. I тільки з волі автора, через його безпосереднє втручання, ця доля може бути змінена. Так, у 
передмові до англомовної версії цього роману Набоков зауважує: „Мы с женою появляемся в двух последних главах только для инспекции" [9, с. 68]. 3'являються вони під іменем- анаграмою Блавдака Віноморі та його дружини разом із сачком для метеликів.

Відчувають присутність автора і герої. Навіть недалекоглядного Франца „...приводило в замешательство и ярость то, что этот проклятый счастливый иностранец <...> знал абсолютно все о его затруднительном положении и, возможно, жалел, не без некоторой насмешки, честного молодого человека, который был совращен и присвоен женщиной старше его по возрасту" [Там само]. Франц із заздрістю дивився на цю незнайому пару, і від цього йому стало ще гірше. Те, що персонажі, здається, буквально розвалюються на уламки, коли їх творець входить у їхній світ наприкінці роману, є, на думку Дж. В. Конноллі [10, с. 617], показником сили автора.

Для глибшого висвітлення окресленої проблеми необхідно розглянути класичну роботу Жерара Женетта „Оповідний дискурс” [Див.: 10, с. 627-628], в якій Женетт називає фокалізацією суму обмежень, накладених на інформацію, доступну оповідачеві. Він передбачає, що оповідач не вигадує події - творення є функцією автора, - а лише оповідає про них читачеві. Як ідеальний горизонт реальність подій існує незалежно від акту оповіді і може бути різною мірою доступною оповідачеві. Інстанцією, відповідальною за ступінь доступності зображеної реальності оповідачеві, $\epsilon$ інстанція фокалізації. Максимальна доступність, включаючи доступність внутрішніх станів персонажів, означає „всезнання” і нульову фокалізацію. Обмежена доступність $\epsilon$ ненульовим ступенем фокалізації, яка й визначає конкретну точку зору. Інстанція оповіді доконче передбачає агента (оповідача), навіть якщо оповідь безособова; таким чином інстанції бачення відповідає свій агент фокалізатор, котрий щодо оповідача $є$ незалежним. Тобто одна точка зору може бути донесена до читача різними голосами, і навпаки, один голос може розповісти історію з різних точок зору.

Можливість ізолювати голос від точки зору дозволяє Набокову ввести неістинність в історію, у якій ідеться про вигадані події, не піддаючи сумніву правдивість оповідача.

Леона Токер з приводу ненадійного фокалізатора у романі В. Набокова „Король. Дама. Валет” висловлюється: „Техніка нерозуміючого фокалізатора є одним із методів, за допомогою яких Набоков <...> створює ілюзію, що вигаданий світ живе своїм життям, 
як певне тло, яке закони візуальної перспективи не дають чітко розгледіти" [14, с. 629].

Автор творить, оповідач тільки розповідає про те, що бачить, але він сам не у фокусі читацького бачення, він споглядає всіх по черзі від Марти до Драйєра і Франца, описує їх збоку і зсередини, зі свідомості самого героя. Читачеві дається така можливість разом 3 оповідачем бути всюдисущим. Те, що оповідач представлений як безособовий, підсилює відчуття ефекту реальності. Увесь рівень оповіді поза межами контролю самих персонажів. Факт того, що потік дискурсу організується по черзі навколо їхніх суб'єктивних точок зору, залишається для них зовсім недоступним. Вони структурують комунікацію між безособовим оповідачем і читачем у ролі фокалізатора. Отож, тільки автор може контролювати всі аспекти свого дискурсу. Читач, своєю чергою, володіє тією повнотою інформації, яка необхідна для правильного розуміння подій. Отож, автор веде рівноправний діалог з читачем, у якому герої грають роль фокалізатора, візуального агента. Прихильний оповідач інформує читача про істинний стан подій. Погоджуємося 3 Г. Хасином [Див. 15, с. 633], який вважає, що така прихильність рідко трапляється у набоковських романах. Зазвичай читач опиняється у такій самій ситуації, як і герой: він помиляється і часто знає менше за всіх. Так, наприклад, в оповіданні „Спостерігач” („Соглядатай”) читач найменш поінформований. Він знає менше, ніж оповідач, i менше, ніж самі герої. Підводячи підсумки, можемо сказати, що набоковські оповідачі $є$ прихильними до тих, хто перечитує, а не знайомиться вперше зі світом роману.

Стосовно набоковських героїв Г. Хасин висловлює думку, що кожен персонаж грає незалежну лінію, аналогічну до партії окремого інструмента в оркестрі, і всі ці лінії разом породжують загальне звучання. Та про це самі персонажі не знають. Це відомо лише читачеві, котрому автор довіряє цю таємницю [15, с. 641].

Зупинимося на одному з останніх романів В. Набокова: „А, вот и нужный мне персонаж. Привет, персонаж! Не слышит,” - цим звертанням розпочинається роман В.Набокова „Прозорі речі”. Репліка-звертання залишається без відповіді. Тому автор звертається знову: „Привет, персонаж! Что такое? Не надо меня оттаскивать. Не собираюсь я к нему приставать. Ну ладно, ладно. Привет, персонаж... (в последний раз, шепотком)” [8, с. 11]. Такий толерантний підхід до персонажа, звичайно, є лише грою, адже 
безпосередньо після цих слів іде репліка: „Когда мы сосредотачиваем внимание на материальном объекте, как бы ни был он расположен, самый акт сосредоточения способен помимо нашей воли окунуть нас в его историю. Новичкам следует научиться скользить над материей, если они желают, чтобы материя оставалась во всякое время точно такой, какой была. Прозрачные вещи, сквозь которые светится прошлое!” [Там само]. Спробуємо на основі цього уривку визначити, яку роль відводить автор героєві і читачеві. Видається, що „матеріальним об'єктом”, на який автор скеровує увагу читача, $є$ герой, що і підтверджує початок другої глави: „В качестве персонажа Хью Персон...”. Читачам, якщо вони $€$ „новачками” у набоковському світі, пропонується зайняти позицію стороннього глядача, коли вони дійсно прагнуть пізнати цей світ об'єктивно. Займенник „ми”, яким послуговується автор під час оповіді, надає його взаєминам з читачами певної інтимності i довіри. Так, він запевняє читача: „...Хью-то не ускользнет, будьте уверены” [8, с. 16] і попереджує: „...все зависит от угла, под которым падает свет, и от расположения наблюдателя" [8, с. 22]. Трохи пізніше ми переконуємося, що так доброзичливо звертається до нас не сам автор, а лише його агент, який підзвітний авторові: „Теперь у нас в фокусе главная улица <...>. Улица кишит прозрачными людьми и процессами, в которые или сквозь которые мы бы могли уплыть с упоением ангела или автора (виділено нами. - Т.Ч.), но для настоящего отчета нам надлежит выделить одну лишь персону Персона” [8, с. 45]. (Звернемо увагу на гру слів „ангел-автор” і „персону Персона”, яка ще раз доводить позицію верховенства автора, який може бути й ангелом щодо „персони персонажа”). Агент, своєю чергою, підзвітний авторові. Врешті, автор відкритим текстом розставляє все на місця: „...Арманда же знала о будущем (конечно, известном автору в каждой детали) не больше, чем о прошлом <..>. Хью, сентиментальный простак и в общем-то персонаж не из лучших (лучшие выше этого, а он был просто довольно славный)..." [8, с. 48].

Надзвичайно цікавими у цьому романі $\epsilon$ діалоги Персона як літературного редактора з романістом R. Останній про героїв свого роману, яких поставив під сумнів Персон, категорично заявив, що: „можна охолостить кота, но моих персонажей не выхолостишь. <...>. Меня обвиняют в том, что я копаюсь в пустяках, но и пустые личности в моих книгах неприкосновенны" [8, c. 68]. R. пише роман, який нагадує 
читачеві набоковську „Лоліту”, а Персон його готує до видавництва: „Наш Персон, наш читатель, не был вполне уверен, что ему по душе вычурный, и ломаный слог R., и все же в лучших его проявлениях <..> этот слог дьявольски расшевеливал память" [Там само].

Главу 24 можемо вважати безпосереднім зверненнямкоментарем до читача: „Прямое вмешательство в жизнь персонажа - занятие не по нашей части, а с другой, фигурально говоря, стороны, и судьба его не является цепью предопределенных звеньев: кое-какие „будущие” события могут быть вероятней иных, ну и ладно, - все они химеричны, и каждая причинно-следственная цепочка есть итогом проб и провалов <...>. Все, что мы можем сделать, понукая нашего фаворита двигаться в лучшем из направлений <...> это поступить подобно легкому ветерку, и уж коли подталкивать, так очень легко и в высшей степени опосредованно, - скажем, пытаясь наслать нашему фавориту сон, который, мы только надеемся, он припомнит как пророческий, если похожее происшествие и вправду случится" [8, с. 85].

Оповідач не має права прямо впливати на життя персонажа, але він, як посередник автора (у ролі ангела), може зіграти роль подиху вітру долі, щоб скерувати героя (згадаймо порівняння з монадами Лейбніца). Оповідач зізнається, що на друкованій сторінці „ми” багато в чому залежимо від курсиву, адже правом виділяти курсивом володіє автор. Тому життя людини порівнюється 3 персонажем, „танцующим во множестве обличий вкруг собственного „я"...” [8, с. 86].

Як і в інших романах Набокова, герой відчуває всюди присутність автора: „Всю свою жизнь, и мы счастливы это отметить, наш Персон испытывал странное ощущение (знакомое трем знаменитым теологам и двум поэтам поплоше (на нашу думку, це - Цинциннат із „Запрошення на страту”, Герман із „Відчаю”, Круг із „Bend Sinister”, Франц із „Король. Дама. Валет” і Мак-Наб із „Дивись на арлекінів”) присутствия за спиной - так сказать, у плеча - гораздо более крупного, невообразимо более мудрого, спокойного и сильного незнакомца, превосходящего его в рассуждении нравственности. В сущности, это и была его главная „сопроводительная тень” <..>, и не будь у него этой сопроводительной тени, мы бы и разговаривать не стали о дорогом нашем Персоне" [8, с. 91]. Персон почув, як дехто або дещо, радять йому виїхати з Вітта. Але він не послухав своєї тіні, „...и в фундаментальном плане был, наверное, прав <...> в конечном 
счете ему оставалось решать и ему умирать, если он того пожелает" [8, с. 92]. Знехтувавши підказкою, він „добровільно” обирає свою долю, заплановану автором, - він помирає під час пожару у тому ж номері, де вісім років тому у стані пророчого, як виявилося, сну задушив Арманду. „Последним его видением была добела раскаленная книга или коробка, становившаяся совершенно прозрачной и совершенно пустой. Вот это, как я считаю, и есть самое главное: не грубая мука телесной смерти, но ни с чем не сравнимая пронзительность мистического мыслительного маневра, потребного для перехода из одного бытия в другое.

И знаешь, сынок, это дело нехитрое” [8, с. 96-97], - цими словами, як ми переконані, зверненням В. Набокова до свого сина, завершується роман. Книга закінчується, з нею помирає персонаж, але залишається сам автор (і він про це нагадує своїм звертанням до сина), для якого життя продовжиться у багатьох наступних чи попередніх його романах, чого ніколи не станеться 3 його персонажем Персоном (тільки за умови, якщо цього захоче автор).

\section{Висновки}

1. В.Набоков сприймав творчість як естетичну гру уяви й інтелекту, що й пояснює його „зверхню” позицію щодо своїх героїв та читачів. Цю зверхність розуміємо як бажання автора зайняти належне йому становище творця, яке дозволяє бути керівною силою (долею) для своїх героїв і передбачає присутність автора у кожній ситуації рецепції, а це найпаче забезпечує „живий” діалог В. Набокова з його читачами.

2. У ставленні до читача у набоковській творчості безпосередньо простежуємо дві паралельні й водночас протилежні позиції: 3 одного боку, це акцентоване ігнорування читацької аудиторії в інтерв'ю й передмовах до англомовних романів, 3 іншого сподівання знайти свого читача власне у текстах романів і віршів. В. Набоков знову веде гру; і від читача залежить, як він сприйме цю гру, що й створює для письменника імідж елітарного інтелектуала. Якщо читач приймає правила гри - його очікує дивовижний діалог не $з$ героями, а з самим автором. Сила уяви допоможе читачеві за умови, якщо він довіриться авторові й захоче розпочати 3 ним діалог, осягнути таємний лад оповіді й отримати від цього естетичне задоволення, яке заплановане автором як нагорода за плідний діалог, що відбувся між ними. 
3. Герой для В. Набокова - це передовсім свідомість, створена автором, тобто це не творча енергія, а творіння, підпорядковане іншій - вищій - авторській волі. Таке розуміння і зумовлює пасивну позицію набоковського героя щодо автора й читача. Герой прямує лише тим шляхом, який для нього накреслює автор. Набоков залишає для своїх героїв можливість перевтілитися із створеного суб'єкта у творчий суб'єкт за однієї умови - читацького бажання. Взаємини автора, героя і читача у набоковській творчості однаково залежать від відповідальності автора й читача. Хоча герой у Набокова і не $є$ самостійним, (саме через свою повну асиміляцію із авторським творчим „я”), він $\epsilon$ невід'ємним компонентом реалізаціії діалогу „автор - герой - читач”, тому що саме у діалозі протилежності творять єдність.

Мусимо погодитися із тим, що мало для кого герої Набокова стануть улюбленими. I це не залежить від них. Зате сама особистість письменника, чиє „тут-буття” присутнє у кожному з цих героїв, може стати близькою, хоча й небагатьом. В. Набоков знав, що не всі сприймуть його творчість і що його читач - це майбутній читач. Тому його твори не розраховані на масового читача. Це зумовлено й авторською зорієнтованістю на елітарного читача, i його естетичною позицією у творчості.

Отож, діалог, запропонований Набоковим, відбувся i буде продовжуватися до тих пір, допоки його читатимуть.

\section{Список використаних джерел:}

1. Аппель А. Интервью, данное Альфреду Аппелю [Монтрё (Швейцария), сент. 1966 г.]. Вопросы литературы. 1988. № 10. С. 161-188.

2. Давыдов С. «Гносеологическая гнусность» Владимира Набокова: Метафизика и поэтика в романе «Приглашение на казнь». Набоков В.В.: Антология pro et contra / Сост. Б. Аверина, М. Маликовой, А. Долинина. СПб.: РХГИ, 1999. С. 476-490.

3. Дымарский M. Deus ex texto, или Вторичная дискурсивность набоковской модели нарратива / Набоков В. В.: Антология pro et contra. Т. 2 / Сост. Б. В. Аверина. СПб.: РХГИ. 2001. С. 236-260.

4. Левинтон $Г$. The Importance of Being Russian или Les allusions perdues / Набоков В. В.: Антология pro et contra / Сост. Б. Аверина, М. Маликовой, А. Долинина. СПб.: РХГИ, 1999. С. 308-339.

5. Лейбниц Г. Сочинения. М., 1982. Т. 1. С. 413-429. 
6. Медведева-Гнатко В. Автор и читатель в ситуации рефлексии / Слово и бытие. Донецк: ДонГУ, 1997. С. 157-172.

7. Михайлов О. В. Набоков: [Литература русского Зарубежья]. Литература в школе. 1991. № 3. С. 42-52.

8. Набоков В. Американский период. Собрание сочинений в 5-ти томах. Т. 5. СПб.: «Симпозиум», 1999. 704 с.

9. Набоков В.: Антология pro et contra / Сост. Б. Аверина, М. Маликовой, А. Долинина; комментарии Е. Белодубровского, Г. Левинтона, М. Маликовой, В. Новикова; библиогр. М. Маликовой. СПб.: РХГИ, 1999. 976 с.

10.Набоков В.: Антология pro et contra. Т. 2 / Сост. Б. В. Аверина, библиогр. С. А. Антонова. СПб.: РХГИ. 2001. 1064 с.

11.Набоков В. О хороших читателях и хороших писателях. Книжное обозрение. 1989. 20 января. № 3. с. 10.

12. Набоков В. Собрание сочинений в 4-х т. М.: Правда, 1990.

13.Ортега-и-ГассетХ. Этюды об Испании. Новый Круг Порт Рояль - Киев. 1994. 320 с.

14.Токер Л. Набоков и этика камуфляжа / Набоков В. В.: Антология pro et contra. Т. 2 / Сост. Б. В. Аверина. СПб.: РХГИ. 2001. С. 377-386.

15.Хасин Г. Между микро и макро: повествование и метафизика в романе В. Набокова «Король, дама, валет» / Набоков В. В.: Антология pro et contra. Т. 2 / Сост. Б. В. Аверина. СПб.: РХГИ. 2001. C. 619-649.

16. Червинская 0. О. Пушкин, Набоков, Ахматова: Метаморфизм русского лирического романа. Черновцы: Рута, 1999. 152 с. 